Check for updates

Cite this: RSC Adv., 2019, 9, 27987

Received 5th July 2019

Accepted 19th August 2019

DOI: $10.1039 / c 9 r a 05121$

rsc.li/rsc-advances

\section{Environmentally friendly nanocrystalline magnesium hydride decorated with metallic glassy- zirconium palladium nanopowders for fuel cell applications $\uparrow$}

\author{
M. Sherif El-Eskandarany, (D) * Mohammad Banyan $\mathbb{D}+$ and Fahad Al-Ajmi $\ddagger$
}

A new solid-state hydrogen storage system of magnesium hydride $\left(\mathrm{MgH}_{2}\right)$ doped with $5 \mathrm{wt} \%$ of metallic glassy (MG) zirconium palladium $\left(\mathrm{Zr}_{2} \mathrm{Pd}\right)$ nanopowder was fabricated using a high-energy ball milling technique. The end-product obtained after $50 \mathrm{~h}$ of milling was consolidated into bulk buttons, using a hot-pressing technique at $350^{\circ} \mathrm{C}$. The results have shown that this consolidation step, followed by the repetitive pressing at ambient temperature did not affect the nanocrystalline characteristics of pressed powders. Recycling pressing demonstrated beneficial effects of plastic deformation and lattice imperfections on $\mathrm{Mg}$, leading to its enhanced hydrogenation/dehydrogenation kinetics and cycle-lifetime performance compared with untreated samples. The results elucidated that spherical, hard, nanopowder of $\mathrm{MG}-\mathrm{Zr}_{2} \mathrm{Pd}$ were forced to penetrate the $\mathrm{Mg} / \mathrm{MgH}_{2}$ matrix to create micro/nanopore structures upon pressing for 50 cycles. These ultrafine spherical metallic glassy particles ( 400 nm in diameter) acted as a micro-milling media for reducing the particle size of $\mathrm{MgH}_{2}$ powders into submicron particles. In addition, they played a vital role as grain growth inhibitors to prevent the undesired growth of $\mathrm{Mg}$ grains upon the application of a moderate temperature in the range of $50{ }^{\circ} \mathrm{C}$ to $350{ }^{\circ} \mathrm{C}$. The apparent activation energy for the decomposition of this new consolidated nanocomposite material was measured to be $92.2 \mathrm{~kJ} \mathrm{~mol}^{-1}$, which is far below than the measured value of pure nanocrystalline $\mathrm{MgH}_{2}$ powders $\left(151.2 \mathrm{~kJ} \mathrm{~mol}^{-1}\right.$ ) prepared in the present study. This new binary system possessed superior hydrogenation kinetics, indicated by the rather low temperature $\left(200{ }^{\circ} \mathrm{C}\right)$ required to uptake $6.08 \mathrm{wt} \% \mathrm{H}_{2}$ within $7.5 \mathrm{~min}$. More importantly, the system revealed excellent dehydrogenation kinetics at $225{ }^{\circ} \mathrm{C}$ as implied by the limited time needed to release $6.1 \mathrm{wt} \% \mathrm{H}_{2}$ in $10 \mathrm{~min}$. The $\mathrm{MgH}_{2} / 5 \mathrm{wt} \% \mathrm{MG}-\mathrm{Zr}_{2} \mathrm{Pd}$ system showed a high performance for cyclability, implied by the achievement of continuous cycles (338 cycles) at $225^{\circ} \mathrm{C}$ without degradation over $227 \mathrm{~h}$.

\section{Introduction}

In contrast to the great challenges tackled in the research activities of alternative green energy, traditional fossil fuels remain the major energy source. ${ }^{1}$ The rapid population growth engaged with economic evolution led to a dramatic growth in fossil fuel consumption in both developed and advanced countries. ${ }^{2-4}$ Accordingly, huge amounts of carbon dioxide and other harmful air pollutants, such as $\mathrm{SO}_{2}$ and $\mathrm{NO}_{x}$, are emitted upon the burning of fossil fuels for power generation. ${ }^{5}$ Recently, it has been pointed out by different authors that two dimensional materials, such as $\mathrm{AlB}_{6},{ }^{6} \mathrm{Cu}_{2} \mathrm{Si},{ }^{7}$ transition metal-

Nanotechnology and Advanced Materials Program, Energy and Building Research Center, Kuwait Institute for Scientific Research, Safat 13109, Kuwait. E-mail: msherif@kisr.edu.kw

$\dagger$ Electronic supplementary information (ESI) available. See DOI: 10.1039/c9ra05121j

\$ Mohammad Banyan and Fahad Al-Ajmi are equally contributed to this work. phthalocyanine (TM-Pc) monolayers, ${ }^{8}$ single atom catalyst TM-TCNQ monolayers, ${ }^{\mathbf{C}}$ transition metal porphyrin sheets, ${ }^{\mathbf{1 0}}$ and $\mathrm{Mn}$-graphene single-atom, ${ }^{\mathbf{1 1}}$ have the potential capacity to catalytically remove gas molecules, such as $\mathrm{CO}_{2}, \mathrm{SO}_{2}$ and $\mathrm{NO}_{x}$, or transform them to other species. Among different sources of new/renewable energy options, hydrogen energy carriers have been receiving great attention due to their attractive and unique properties. Owing to its convenient, safe and unusual characteristics, hydrogen has been proposed as an alternative to fossil fuel. ${ }^{6}$ This is attributed to its convenient production from renewable energy systems (e.g. photovoltaics cells) and the unchallenging procedure used for its conversion into the desired form of energy through fuel cells (FCs). ${ }^{\mathbf{1 , - 9}}$

Hydrogen in its gaseous state has a very high gravimetric energy density (120 MJ kg ${ }^{-1}$ ) compared with petroleum (44 MJ $\mathrm{kg}^{-1}$ ); however, the storage of hydrogen in sufficient quantities is challenging. Unfortunately, the classic methods proposed for the storage of hydrogen in its gaseous and liquid states show 
serious drawbacks due to their high cost and safety issues. In contrast, the solid-state hydrogen storage approach, using for example magnesium ( $\mathrm{Mg}$ ) metal as a storage material shows promising practical solutions ${ }^{\mathbf{1 0 , 1 1}}$ due to its reliability, safety and cost effectiveness. Accordingly, $\mathrm{Mg}$, its alloys and compounds have been attracting many researchers in both developed and advanced countries. ${ }^{4}$ Such a rather new approach has been proposed as the most suitable technique for fuel cell vehicle applications. ${ }^{7,9-12}$ It is realized that some poor behaviors found in $\mathrm{Mg}$ (e.g. large negative enthalpy change of formation, slow hydrogenation/dehydrogenation kinetics below $350{ }^{\circ} \mathrm{C}$, high thermal stability and large apparent value of activation energy) must be solved first before proposing the system for hydrogen storage applications.

Among different methods proposed to improve the hydrogen storage behaviors of $\mathrm{Mg}$ (e.g. long term of milling, severe plastic deformation techniques), doping the metal with metallic catalytic agent(s) via high-energy ball milling has shown significant improvements in its behaviors. ${ }^{13}$ Of these catalysts, pure metals, such as Ni-nanofibers, ${ }^{14} \mathrm{Zr},{ }^{15}$ and Nb-nanoparticles, ${ }^{16}$ had superior effects on reducing the apparent activation energy and minimizing the time required for full absorption/desorption processes. Intermetallic compounds and alloys, such as $\mathrm{Ti}_{0.4^{-}}$ $\mathrm{Cr}_{0.15} \mathrm{Mn}_{0.15} \mathrm{~V}_{0.3},{ }^{17} \mathrm{ZrCrNi}^{18}{ }^{18} \mathrm{TiAl},{ }^{19} \mathrm{LaNi}_{5}{ }^{{ }^{20}} \mathrm{ZrNi}_{5}$ materials. ${ }^{21}$ More recently, metastable amorphous and metallic glassy alloys $^{22-25}$ and quasicrystal phases ${ }^{26}$ have shown superior effects on improving the kinetic characteristics of $\mathrm{MgH}_{2}$ materials. Table S1† summarizes the hydrogen storage properties of $\mathrm{MgH}_{2}$ upon doping with selected metallic catalytic systems. ${ }^{30-35}$

The present study has been conducted to investigate the possibility of improving the hydrogen storage behavior of nanocrystalline $\mathrm{MgH}_{2}$ powders upon doping and reactive ball milling (RBM) with different molecular fractions $(2.5,5$, and $10 \mathrm{wt} \%$ ) of metallic glassy (MG) $\mathrm{Zr}_{2} \mathrm{Ni}$ nanopowders (used here for the first time). More importantly, we have attempted to employ this new nanocomposite system for running an electric golf-cart, using a $1000 \mathrm{~W}$ proton-exchange membrane fuel cell (PEM-FC).

\section{Methods}

\section{Materials preparation}

Nanocrystalline $\mathbf{M g H}_{2}$ powders. Pure $\mathrm{Mg}$ (99.8 wt\%) powder ( $80 \mu \mathrm{m}$ in diameter) provided by Sigma-Aldrich, St. Louis, Missouri, USA and hydrogen gas (99.99 wt\%) supplied by a local gas-company in Kuwait were used as starting materials for conducting the gas-solid reaction through the RBM technique. The powders were balanced in a glove box under high purity (99.99 wt\%) He gas and sealed into a tool steel vial $(220 \mathrm{ml}$ in volume) together with 50 tool-steel balls (10 $\mathrm{mm}$ in diameter); a ball-to-powder weight ratio of $40: 1$ was used. The vial was pressurized with 70 bar of $\mathrm{H}_{2}$, and then mounted on a highenergy ball mill (PM 400, Retsch-Germany). The RBM process was performed at ambient temperature with a speed of $300 \mathrm{rpm}$. The end-product of the powders obtained after milling for $25 \mathrm{~h}$ was completely discharged in the glove box, where a new $\mathrm{Mg}$ powder batch was charged into the vial. This procedure, including RBM was repeated for 40 times to obtain about $250 \mathrm{~g}$ of $\mathrm{MgH}_{2}$ powders.

Metallic glassy (MG)-Zr $\mathbf{Z}_{2}$ Pd nanopowders. Elemental Zr (20 $\mu \mathrm{m} 99.6 \mathrm{wt} \%)$ and Pd (5 $\mu \mathrm{m}, 99.9 \mathrm{wt} \%)$ provided by SigmaAldrich were balanced in the glove box to give the nominal composition (at\%) of $\mathrm{Zr}_{67} \mathrm{Pd}_{33}$ and were well mixed before sealing into a tool steel vial (220 ml in volume) together with 25 tool-steel balls (10 $\mathrm{mm}$ in diameter); a ball-to-powder weight ratio of $20: 1$ was used. The mechanical alloying process (MA) was started by mounting the vial on a high-energy ball mill (PM 100, Retsch-Germany) and running it for $25 \mathrm{~h}$ at $250 \mathrm{rpm}$. This process was repeated for 10 times to obtain about $50 \mathrm{~g}$ of the powders.

Nanocomposite $\mathrm{MgH}_{2} / x$ wt\% $\left(x ; 2.5,5\right.$ and 10) ${\mathrm{MG}-\mathrm{Zr}_{2} \mathrm{Pd}}$ nanopowders. The as-fabricated $\mathrm{MgH}_{2}$ powders were mixed with $x$ wt\% $(x ; 2.5,5$, and 10$)\left[\mathrm{MG}-\mathrm{Zr}_{2} \mathrm{Ni}\right]$ and ball milled under hydrogen for $50 \mathrm{~h}$, using a high-energy ball mill that operated at 200 rpm. The composite powders (Fig. 1a) were consolidated into buttons with a $50 \mathrm{~mm}$ diameter and a relative density that varied from $96 \%$ to $98 \%$, using a 15 -ton hot-press (Fig. 1b) operated under vacuum at $480{ }^{\circ} \mathrm{C}$. The relative density was improved to reach $99 \%$ upon repressing the buttons for 50 cycles. During the repressing procedure, the hard, spherical, $\mathrm{MG}-\mathrm{Zr}_{2} \mathrm{Ni}$ powders tend to penetrate the $\mathrm{Mg}$ matrix and form micropores, as schematically presented in Fig. 1c. These cavities hosted $\mathrm{MG}-\mathrm{Zr}_{2} \mathrm{Ni}$ catalysts to create hydrogen diffusion pathways, as shown in Fig. 1d.

\section{Sample characterization}

Crystal structure. $\mathrm{X}$-ray diffraction $(\mathrm{XRD})$, with $\mathrm{Cu}-\mathrm{K} \alpha$ radiation using a $9 \mathrm{~kW}$. Intelligent X-ray diffraction system that was (a)
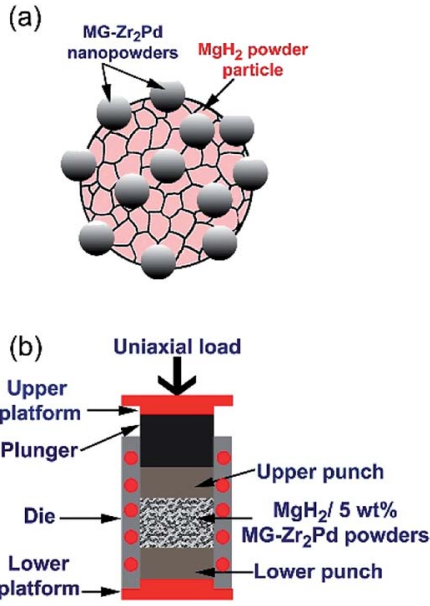

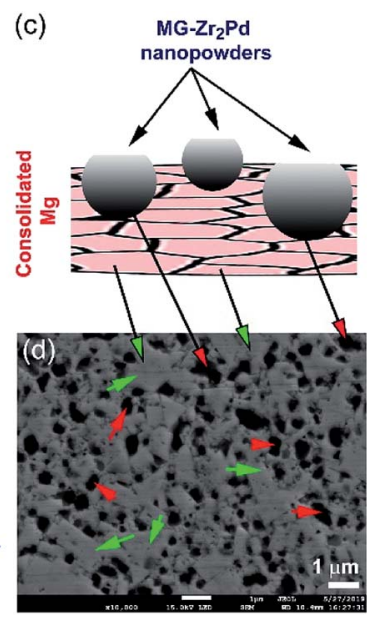

Fig. 1 Schematic presentations elucidate (a) aggregated $\mathrm{MgH}_{2}$ powders doped with $\mathrm{MG}-\mathrm{Zr}_{2} \mathrm{Pd}$ nanopowder particles obtained after $50 \mathrm{~h}$ of RBM, (b) hot-pressing of the nanocomposite powders, using a 20 -ton press, (c) penetration of the $\mathrm{Mg}$ matrix by $\mathrm{MG}-\mathrm{Zr}_{2} \mathrm{Pd}$ nanopowders during the hot-pressing procedure. A low-magnification field-emission electron microscopy (FE-SEM) micrograph for polished nanocomposite $\mathrm{MgH}_{2} / 5 \mathrm{wt} \% \mathrm{MG}-\mathrm{Zr}_{2} \mathrm{Pd}$ buttons obtained after repressing for 50 cycles is shown in (d). The microspore cavities are shown by red arrows, while the Mg metallic matrix is shown by green arrows. 
provided by SmartLab-Rigaku, Akishima-shi, Tokyo-Japan, was used to investigate the general crystal structure of all samples. A field emission high-resolution transmission electron microscope (FE-HRTEM) operated at $200 \mathrm{kV}$ (2100F-field emission high resolution, supplied by JEOL, Musashino, Akishima, Tokyo-Japan) was used to study the structure and morphology of samples. The microscope was equipped with a scanning transmission electron microscopy (STEM) unit interfaced with an energy-dispersive X-ray spectroscopy (EDS) system, supplied by Oxford Instruments, Abingdon-UK. These units were employed to conduct the local elemental analysis of the samples. However, the chemical composition of some samples were determined using inductively coupled plasma mass spectrometry (ICP-MS) provided by Shimadzu Scientific Instruments, Saitama-Japan.

The XRD pattern of the starting mixture powder of $\mathrm{Zr}_{67} \mathrm{Pd}_{33}$ is presented in Fig. 2. The powders at this initial stage $(0 \mathrm{~h})$ of MA revealed high-intensity Bragg peaks, corresponding to hcp$\mathrm{Zr}$ and fcc-Pd metals (Fig. 2a). After $25 \mathrm{~h}$ of MA time, these elemental Bragg lines were replaced by a halo-diffuse pattern (Fig. 2b), implying the formation of amorphous $\mathrm{Zr}_{2} \mathrm{Pd}$.

Morphology. A $15 \mathrm{kV}$ FE-scanning electron microscope (FESEM), provided by JEOL, Musashino, Akishima, Tokyo-Japan, was used to perform the morphological characterizations of the powder samples and cold-pressed buttons. The microscope was interfaced with an EDS unit, supplied by Oxford Instruments, Abingdon-UK, which was used to analyze the consolidated samples.

The FE-SEM micrographs of $\mathrm{MG}^{-\mathrm{Zr}_{2}} \mathrm{Pd}$ and $\mathrm{MgH}_{2}$ powders obtained after MA and RBM times of $25 \mathrm{~h}$ are shown in Fig. 3a and b, respectively. Metallic glassy powders had a spherical-like morphology with an average particle diameter of $400 \mathrm{~nm}$ (Fig. 3a). In contrast, $\mathrm{MgH}_{2}$ powders were bulky and had
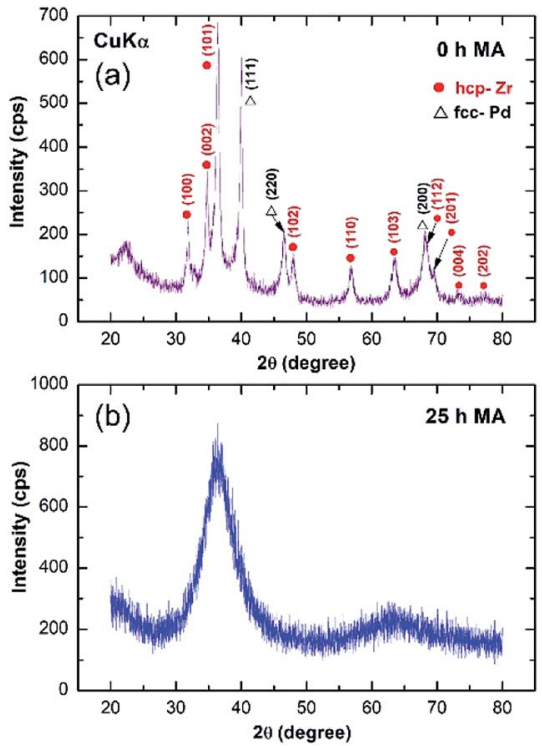

Fig. 2 XRD patterns of elemental $\mathrm{Zr}_{67} \mathrm{Pd}_{33}$ powders after (a) $\mathrm{O} \mathrm{h}$ and $25 \mathrm{~h}$ of mechanical alloying (MA), using a high-energy planetary ball mill. The primary and secondary haloes shown in (b) indicate the formation of the metallic glassy (MG) $\mathrm{Zr}_{2} \mathrm{Pd}$ phase.
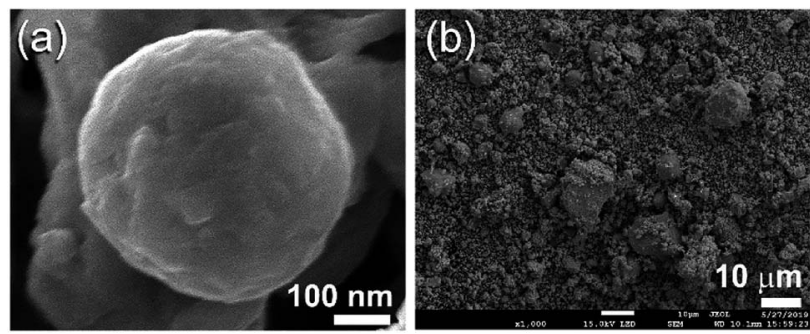

Fig. 3 FE-SEM micrographs of (a) a single MG-Zr ${ }_{2} P d$ particle obtained after $25 \mathrm{~h}$ of $\mathrm{MA}$, and (b) $\mathrm{MgH}_{2}$ powders obtained after $50 \mathrm{~h}$ of RBM.

irregular shapes with a wide particle size distribution $(3 \mu \mathrm{m}$ to $18 \mu \mathrm{m}$ in diameter), as displayed in Fig. $3 \mathrm{~b}$.

Thermal analysis. The desorption behaviors of the powder and consolidated samples were characterized by a Shimadzu Thermal Analysis System/TA-60WS, Saitama-Japan, under a He (99.99 wt\%) gas flow $\left(75 \mathrm{ml} \mathrm{min}^{-1}\right)$. The apparent activation energy $\left(E_{\mathrm{a}}\right)$ of the decomposition was obtained using an Arrhenius approach with different heating rates $(5,10,20,30$, and $40{ }^{\circ} \mathrm{C} \min ^{-1}$ ).

Thermal analysis conducted via DSC was employed to understand the thermal stability of starting feedstock materials as well as the nanocomposite samples obtained after $50 \mathrm{~h}$ of RBM. The DSC thermograms of $\mathrm{MgH}_{2}$ and $\mathrm{MG}-\mathrm{Zr}_{2} \mathrm{Pd}$ powders obtained after $50 \mathrm{~h}$ of RBM and $25 \mathrm{~h}$ of MA are displayed in Fig. 4a and b, respectively. Pure $\mathrm{MgH}_{2}$ powders decomposed through an endothermic peak into $\mathrm{Mg}$ and hydrogen at a high temperature of $349^{\circ} \mathrm{C}$, as presented in Fig. 4a. The DSC trace for
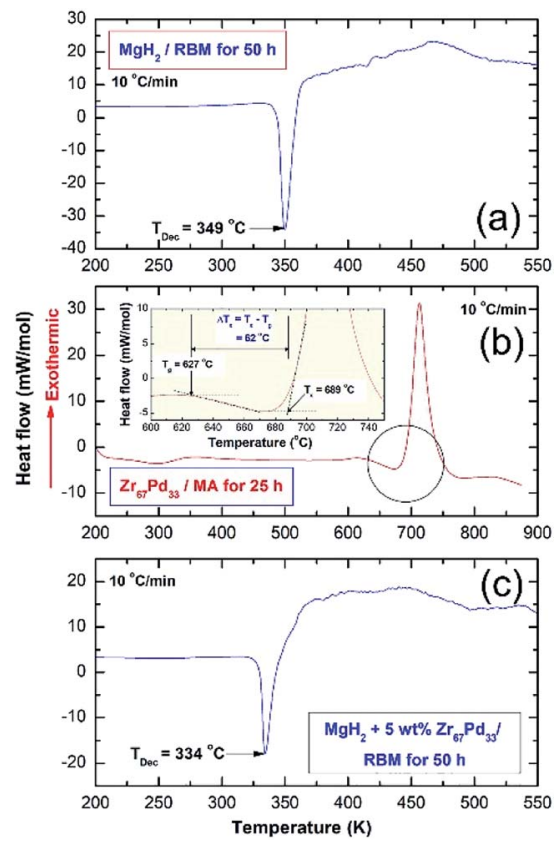

Fig. 4 Helium-atmospheric pressure- DSC traces developed at heating rates ( $k$ ) of $10^{\circ} \mathrm{C} \mathrm{min}^{-1}$ for (a) $\mathrm{MgH}_{2}$ powders obtained after $50 \mathrm{~h}$ of RBM, (b) MG- $\mathrm{Zr}_{2} \mathrm{Pd}$ nanopowder particles after $25 \mathrm{~h}$ of MA and (c) a cold-pressed nanocomposite $\mathrm{MgH}_{2} / 5$ wt\% $\mathrm{MG}-\mathrm{Zr}_{2} \mathrm{Pd}$ button. 
MG- $\mathrm{Zr}_{2} \mathrm{Pd}$ revealed two opposite endothermic and exothermic peaks, as displayed in Fig. 4b, where, the endothermic peak corresponds to the glass transformation process taken place at $627{ }^{\circ} \mathrm{C}\left(T_{\mathrm{g}}\right)$; the sharp exothermic peak appears at an onset temperature $\left(T_{x}\right)$ of $689{ }^{\circ} \mathrm{C}$ due to the crystallization of the metallic glassy phase (Fig. $4 \mathrm{~b}$ ). The value of the supercooled liquid region $\left(\Delta T_{x}=T_{x}-T_{\mathrm{g}}\right)$ for this binary glassy phase, which was calculated to be $62{ }^{\circ} \mathrm{C}$, indicates the high stability of this phase.

The DSC trace of nanocomposite $\mathrm{MgH}_{2} / 5$ wt $\%{\mathrm{MG}-\mathrm{Zr}_{2} \mathrm{Pd}}$ powders obtained after RBM for $50 \mathrm{~h}$ is displayed in Fig. $5 \mathrm{c}$. The sample revealed a single decomposition endothermic event centered at a peak temperature of $334{ }^{\circ} \mathrm{C}$ (Fig. 4c). This value, which was lower than the one shown for pure $\mathrm{MgH}_{2}$ indexed in Fig. $4 \mathrm{a}\left(349^{\circ} \mathrm{C}\right)$, indicates a significant effect of $\mathrm{MG}-\mathrm{Zr}_{2} \mathrm{Pd}$ for decreasing the decomposition temperature of $\mathrm{MgH}_{2}$.

De/rehydrogenation kinetics behavior. Sievert's method, using PCTPro-2000 supplied by Setaram Instrumentation, Caluire-et-Cuire, France, was employed to obtain hydrogen absorption/desorption kinetics. The samples were examined at different temperatures in the range of $50{ }^{\circ} \mathrm{C}$ to $225{ }^{\circ} \mathrm{C}$ under hydrogen gas pressures of 200 mbar (dehydrogenation) and 10 bar (hydrogenation).

Cycle-life-time. The performance of the samples was examined by a cycle-life-time test for $227 \mathrm{~h}$. The materials were first activated at 35 bar of hydrogen at $350^{\circ} \mathrm{C}$ for $50 \mathrm{~h}$. This treatment was necessary to remove the $\mathrm{MgO}$ layer deposited on the sample and to create pathways for the hydrogen desorption/absorption processes. The test was then started at $225{ }^{\circ} \mathrm{C}$ under dehydrogenation and hydrogenation pressures of $200 \mathrm{mbar}$ and $10 \mathrm{bar}$, respectively.

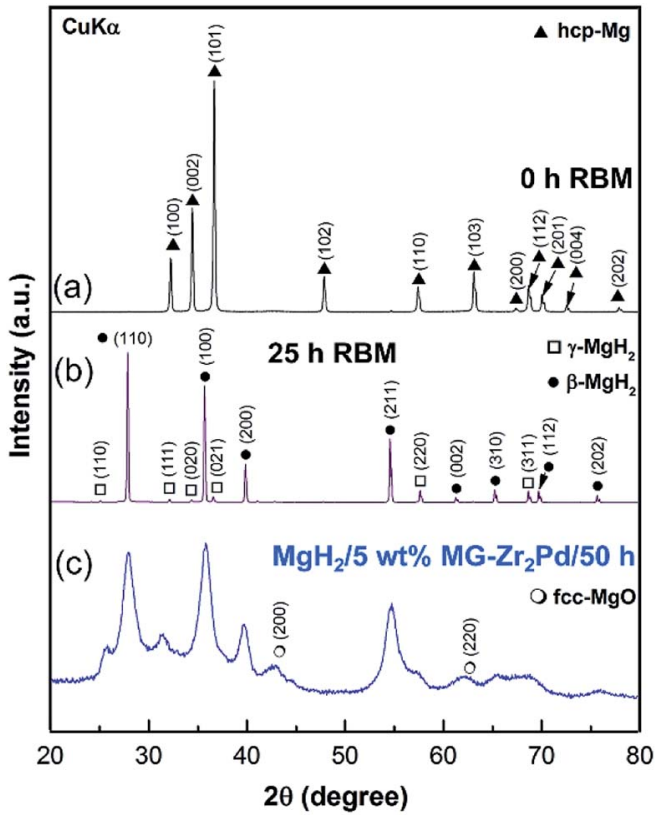

Fig. 5 XRD patterns of (a) starting $M g$ elemental powders, at $0 \mathrm{~h}$ and (b) after $25 \mathrm{~h}$ of RBM, and the XRD pattern of $\mathrm{MgH}_{2} / 5 \mathrm{wt} \% \mathrm{MG}-\mathrm{Zr}_{2} \mathrm{Pd}$ powders obtained after $50 \mathrm{~h}$ of RBM is displayed in (c). XRD pattern of as- $\mathrm{RBM} \mathrm{MgH} \mathrm{H}_{2}$ powders obtained after $50 \mathrm{~h}$ of milling time is presented in Fig. S1.†

\section{Results and discussion}

\section{Structural analysis and morphology}

XRD patterns of the elemental $\mathrm{Mg}$ polycrystalline metal powder used as the feedstock material to synthesize $\mathrm{MgH}_{2}$ is shown in Fig. 5a. The powder was consisted of large grains, characterized by sharp Bragg peaks of hcp-Mg (PDF file \# 00-004-0770). After $25 \mathrm{~h}$ of RBM under 50 bar of hydrogen, Bragg lines of $\mathrm{Mg}$ completely disappeared and were replaced by a new set of diffracted lines, corresponding to stable $\beta$-(PDF file \# 00-012-0697) and metastable $\gamma-\mathrm{MgH}_{2}$ (PDF file \# 00-035-1184) phases, as shown in Fig. 5b. Longer RBM time $(50 \mathrm{~h})$ led to more grain refining, as suggested by the further broadening of Bragg peaks shown in Fig. S1. $\dagger$ The absence of elemental Mg Bragg lines implied the completion of the RBM process.

In order to investigate the doping effect of amorphous $\mathrm{Zr}_{2} \mathrm{Pd}$ on the hydrogen storage properties of $\mathrm{MgH}_{2}$ powders, the metal hydride was decorated with different weight percentages $(2.5,5$ and $10 \mathrm{wt} \%$ ) of $\mathrm{Zr}_{2} \mathrm{Pd}$ and high-energy ball milled for selected RBM times under 50 bar of hydrogen gas pressure. The XRD pattern of the as-ball milled $\mathrm{MgH}_{2}$ decorated with $5 \mathrm{wt} \% \mathrm{Zr}_{2} \mathrm{Pd}$ for $50 \mathrm{~h}$ is presented in Fig. $5 \mathrm{c}$.

As presented, the metal hydride phases revealed very broad Bragg peaks, implying the formation of nanocrystalline powder particles (Fig. 5c). The powder refinement was attained as a result of high energy milling and the presence of hard amorphous powders that played the role of micro-milling media. The shift shown in the background of Fig. $5 \mathrm{c}$ between $2 \theta=30^{\circ}$ to $42^{\circ}$ was attributed to the existence of the $\mathrm{Zr}_{2} \mathrm{Pd}$ amorphous phase in the composite powders.

The bright field (BF) HRTEM image of the aggregated $\mathrm{MgH}_{2} /$ $5 \mathrm{wt} \% \mathrm{Zr}_{2} \mathrm{Pd}$ powders obtained after $50 \mathrm{~h}$ of $\mathrm{RBM}$ is shown in Fig. 6a.

At this final stage of $\mathrm{RBM}, \mathrm{MgH}_{2}$ powders had ultrafine grains ( $\sim 10$ to $20 \mathrm{~nm}$ in diameter), as displayed in Fig. 6a. The Miller-indexed selected area diffraction pattern (SADP) taken from zone I indexed in Fig. 6a shows continuous DebyeScherrer rings related to a tetragonal phase $\left(\beta-\mathrm{MgH}_{2}\right)$

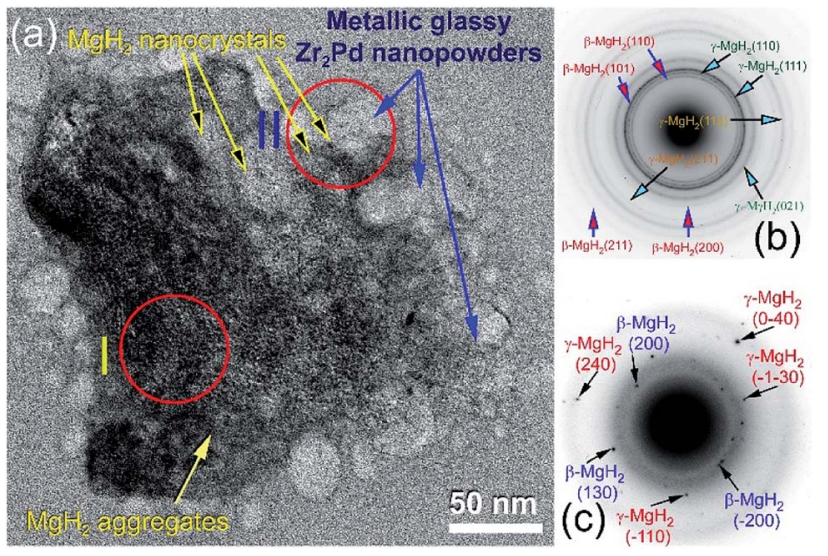

Fig. 6 (a) $\mathrm{BFI}$ of nanocomposite $\mathrm{MgH}_{2} / 5 \mathrm{wt} \% \mathrm{Zr}_{2} \mathrm{Pd}$ obtained after $50 \mathrm{~h}$ of RBM. The SADPs related to zones I and II indexed in (a) are presented in (b) and (c), respectively. 
overlapped with a metastable orthorhombic $\gamma-\mathrm{MgH}_{2}$ phase (Fig. 6b). The absence of spots from the SADP indicates the formation of nanocrystalline $\mathrm{MgH}_{2}$ ultrafine powder particles. Spherical fine particles adhered to the $\mathrm{MgH}_{2}$ aggregate (Fig. 6a) were amorphous $\mathrm{Zr}_{2}$ Pd nanopowders, as confirmed by nanobeam diffraction (NBD) taken from zone II in Fig. 6a and displayed in Fig. 6c. The NBDP revealed a typical halo-diffuse fashion of an amorphous phase coexisting with a spot-pattern related to fine $\mathrm{MgH}_{2}$ crystals precipitated in metallic glassy powders, as presented in Fig. 6c.

Fig. 7a displays the FE-SEM micrograph of $\mathrm{MgH}_{2}$ powders milled with 5 wt\% MG- $\mathrm{Zr}_{2} \mathrm{Pd}$ nanopowders for $12.5 \mathrm{~h}$. The spherical dispersoids of nanopowders indexed in Fig. 7a are metallic glassy particles adhered to the outermost shell of $\mathrm{MgH}_{2}$ powders. After $50 \mathrm{~h}$ of RBM time (Fig. 7b), these decorated nanoparticles penetrated the surface of $\mathrm{MgH}_{2}$ powders by the attrition action of milling the tools to create circular-like micropores in the powder matrix after $50 \mathrm{~h}$ of RBM, as presented in Fig. $7 \mathrm{~b}$.

During the hot-pressing procedure (Fig. 1b) that took place under vacuum at $350{ }^{\circ} \mathrm{C}$ to obtain bulk nanocomposite buttons (Fig. 8a), $\mathrm{MgH}_{2}$ powder matrix was completely decomposed to form sharp-edged metallic $\mathrm{Mg}$ grains, as presented in Fig. 8b. Moreover, MG- $\mathrm{Zr}_{2} \mathrm{Pd}$ nanoparticles deeply "sunk" into those micropores, as shown in Fig. 8b, by the action of uniaxial load pressing applied to nanocomposite powders. In order to ensure that all the decorated

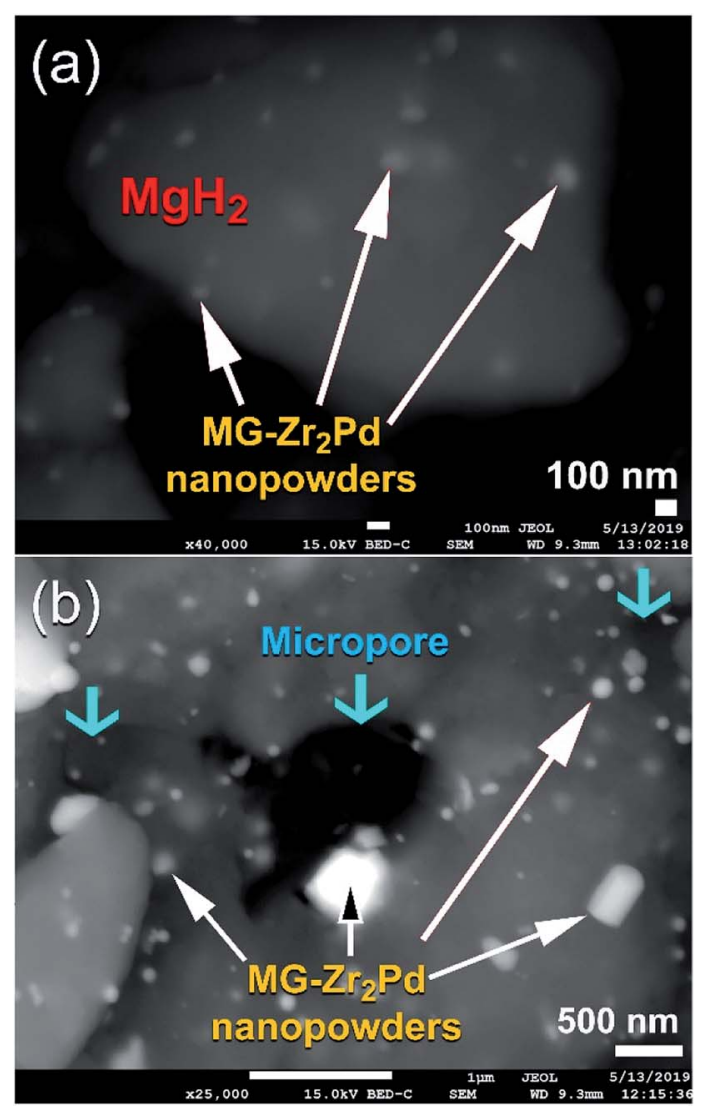

Fig. 7 FE-SEM micrographs of nanocomposite $\mathrm{MgH}_{2}$ powders doped with MG-Zr 2 Pd particles obtained after RBM for (a) $12.5 \mathrm{~h}$ and (b) $50 \mathrm{~h}$.
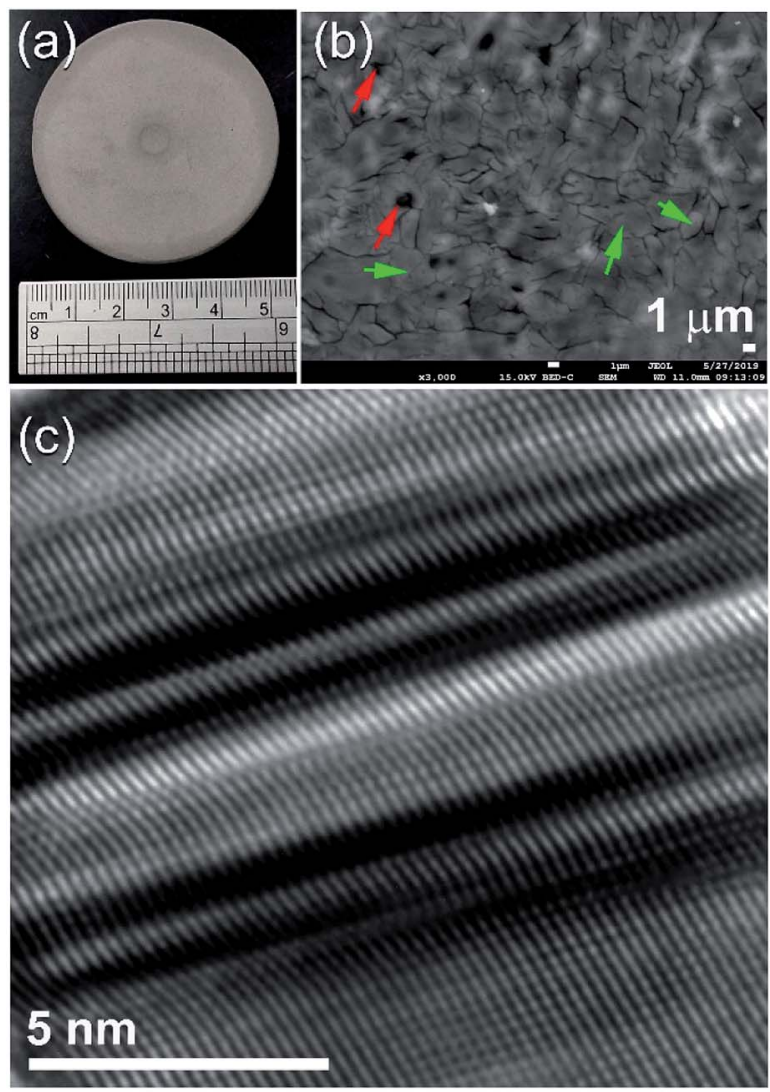

Fig. 8 (a) A photo of the nanocomposite bulk button obtained after 50 -cycles of pressing. The FE-SEM and FE-HRTEM micrographs for the button's cross-sectional views are presented in (b) and (c), respectively.

MG-nanoparticles were embedded into the $\mathrm{Mg}$ matrix, and to introduce severe plastic deformation to the $\mathrm{Mg}$ matrix, the powders were repressed for 50 continuous cycles at $150{ }^{\circ} \mathrm{C}$ to obtain a nearly dense $(\sim 85 \%)$ button, as shown in Fig. 8a.

The cross-sectional view of the polished sample obtained after 50-hot pressing cycles is presented in Fig. 8b. The sample revealed obvious grain boundary dislocations, yielded as a result of the repetition of applied repressing loading. As this repressing procedure was achieved at a low temperature $\left(150^{\circ} \mathrm{C}\right), \mathrm{Mg}$ grains, which are shown by the green labels in Fig. $8 \mathrm{~b}$, maintained their ultrafine characteristics with the absence of grain growth, as presented in Fig. 8b. More importantly, the hot-pressing step did not lead to changes in the porous structure of the sample, as indicated by the existing micropores indexed by the red labels in Fig. 8b. Fig. 8c displays the FE-HRTEM image of the asconsolidated $\mathrm{Mg} / 5 \mathrm{wt} \% \mathrm{MG}-\mathrm{Zr}_{2} \mathrm{Pd}$ nanocomposite obtained after hot pressing for 50 cycles. The 001 plane of hcp-Mg showed a severe planar defect, indexed by clear twin bands and stacking faults, as presented in Fig. 8c. These plastic deformations and lattice imperfections were introduced to the $\mathrm{Mg}$ matrix upon the repressing procedure at a moderate temperature $\left(150^{\circ} \mathrm{C}\right)$.

\section{Thermal stability}

In order to realize the effect of doping $\mathrm{MgH}_{2}$ with the metallic glassy phase on the decomposition process at 1 bar of He, DSC 
experimental sets were individually conducted for pure $\mathrm{MgH}_{2}$ and nanocomposite samples at different heating rates, $k(5,10$, 20,30 and $40{ }^{\circ} \mathrm{C}$ ). The peak temperatures corresponding to each heating run of both samples were recorded from Fig. 9a and b to design the Arrhenius plots for pure $\mathrm{MgH}_{2}$ (Fig. 9c) and nano-

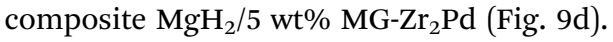

The apparent activation energies of decomposition $\left(E_{\mathrm{a}}\right)$, calculated from the slopes of the straight lines shown in Fig. S3f $\dagger$ (pure $\mathrm{MgH}_{2}$ sample) and Fig. S3g† (nanocomposite sample) were 151.2 and $92.2 \mathrm{~kJ} \mathrm{~mol}^{-1}$, respectively. It can be concluded that doping $\mathrm{MgH}_{2}$ with $\mathrm{MG}^{-\mathrm{Zr}_{2}} \mathrm{Pd}$ nanopowders led to an improved decomposition kinetics behavior of $\mathrm{MgH}_{2}$ and lowered its decomposition temperature. The $E_{\mathrm{a}}$ of the present system is lower than those reported for $\mathrm{MgH}_{2} / 10 \mathrm{wt} \% \mathrm{SrFe}_{12} \mathrm{O}_{19}$ $\left(114.22 \mathrm{~kJ} \mathrm{~mol}^{-1}\right),{ }^{27} 10 \mathrm{wt} \% \mathrm{MgFe}_{2} \mathrm{O}_{4}$-doped $\mathrm{MgH}_{2}$ composite (99.9 kJ mol), ${ }^{28} \mathrm{Mg}-\mathrm{V}$ nanocomposite $\left(147.7 \mathrm{~kJ} \mathrm{~mol}^{-1}\right),{ }^{29}$ and $\mathrm{Mg}-\mathrm{Fe}\left(118.1 \mathrm{~kJ} \mathrm{~mol}^{-1}\right) .{ }^{29}$ However, it is higher than those of $\mathrm{MgH}_{2} / 10$ wt $\%$ Ni nanofiber $\left(72 \mathrm{~kJ} \mathrm{~mol}^{-1}\right),{ }^{14} \mathrm{MgH}_{2} / 10 \mathrm{wt} \% \mathrm{Nb}$ nanoparticles $\left(86.4 \quad \mathrm{~kJ} \mathrm{~mol}^{-1}\right){ }^{16} \mathrm{MgH}_{2} / 20$ wt\% $\mathrm{Ti}_{0.4} \mathrm{Cr}_{0.15^{-}}$ $\mathrm{Mn}_{0.15} \mathrm{~V}_{0.3}\left(71.2 \mathrm{~kJ} \mathrm{~mol}^{-1}\right),{ }^{17}$ and $\mathrm{MgH}_{2} / 7 \mathrm{wt} \%$ amorphous-LaNi ${ }_{3}$ $\left(73.3 \mathrm{~kJ} \mathrm{~mol}^{-1}\right){ }^{25}$

\section{Hydrogenation/dehydrogenation kinetics}

Hydrogenation kinetics measured at 10 bar of $\mathrm{H}_{2}$ at $200{ }^{\circ} \mathrm{C}$ for nanocomposite $\mathrm{MgH}_{2} / x$ MG- $\mathrm{Zr}_{2} \mathrm{Pd}$ powders $(x ; 2.5,5$, and $10 \mathrm{wt} \%$ ) obtained after $50 \mathrm{~h}$ of RBM are displayed in Fig. 10a. In general, all samples that contained different concentrations of MG- $\mathrm{Zr}_{2} \mathrm{Pd}$ had an excellent ability to absorb hydrogen in a short time at such a rather low temperature. The sample that contained $2.5 \mathrm{wt} \% \mathrm{Zr}_{2} \mathrm{Pd}$ absorbed 3.3 and $3.81 \mathrm{wt} \% \mathrm{H}_{2}$ within 5 and $10 \mathrm{~min}$, respectively, as shown in Fig. 10a. It reached higher values after $45 \mathrm{~min}\left(4.56 \mathrm{wt} \% \mathrm{H}_{2}\right)$ and got saturated at $4.89 \mathrm{wt} \%$ $\mathrm{H}_{2}$ after a long time (103 $\left.\mathrm{min}\right)$, as elucidated in Fig. 10a. Increasing the $\mathrm{Zr}_{2} \mathrm{Pd}$ content to $5 \mathrm{wt} \%$ led to an improvement in the hydrogenation kinetics of $\mathrm{MgH}_{2}$, as indexed by the high hydrogen concentration obtained $(5.93 \mathrm{wt} \%)$ in a short time $(5$
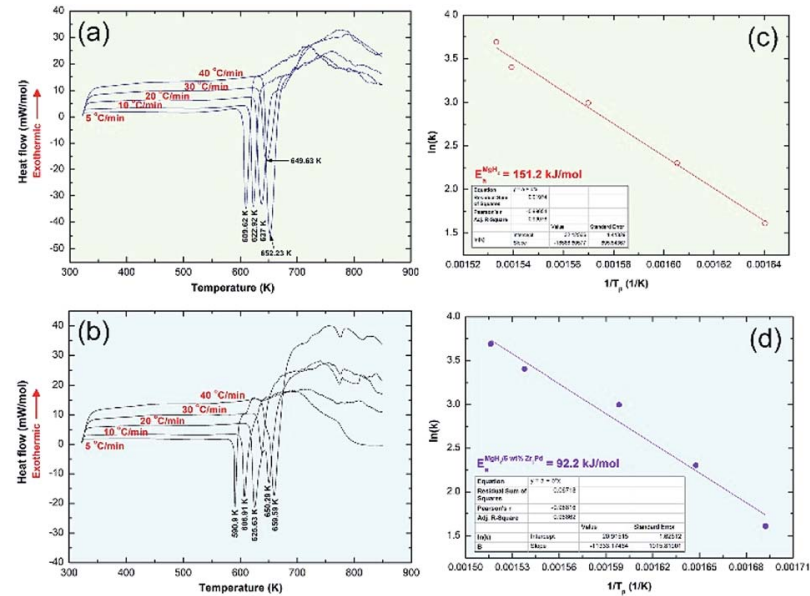

Fig. 9 DSC developed at different heating rates of 5, 10, 20, 30 and $40{ }^{\circ} \mathrm{C} \mathrm{min}^{-1}$ for (a) $\mathrm{MgH}_{2}$ and (b) $\mathrm{MgH}_{2} / 5$ wt\% $\mathrm{Zr}_{2} \mathrm{Pd}$ nanocomposite. The $E_{a}$ decomposition calculated from the results shown in (a) and (b) using the Arrhenius approach are displayed in (c) and (d), respectively.
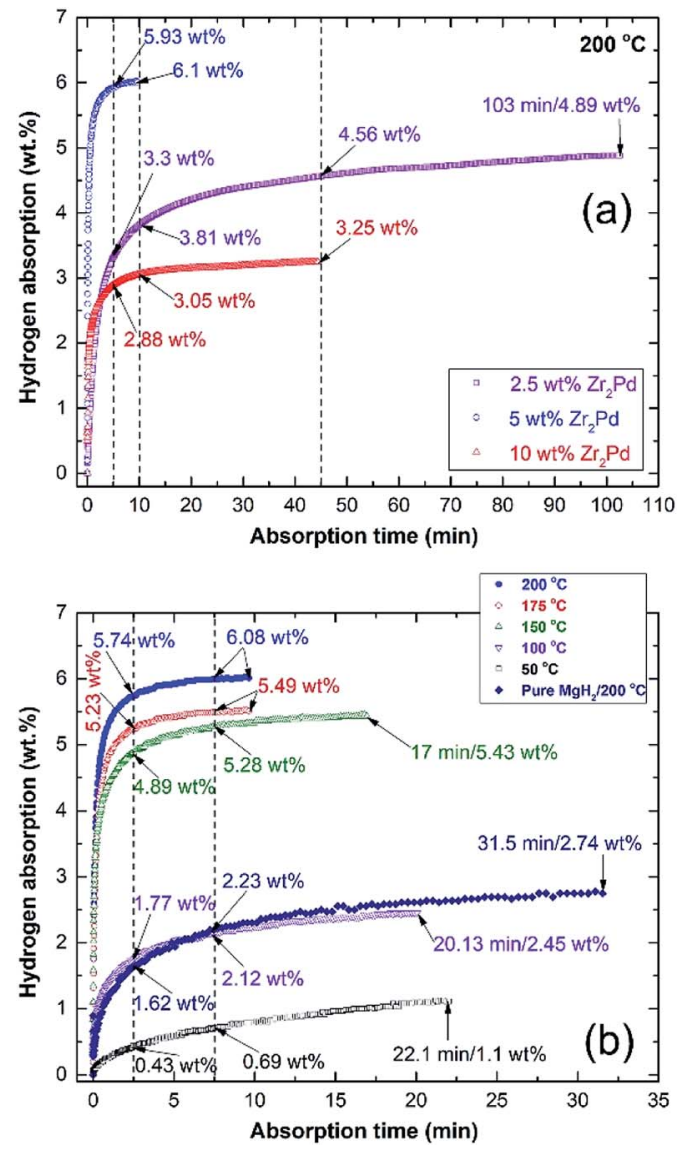

Fig. 10 (a) Hydrogenation kinetics behavior measured at $200{ }^{\circ} \mathrm{C}$ under 10 bar of $\mathrm{H}_{2}$ for $\mathrm{MgH}_{2} / x$ MG-Zr ${ }_{2}$ Pd powders ( $x ; 2.5,5$, and 10 wt\%) after RBMed for $50 \mathrm{~h}$, and (b) as-hot pressed nanocomposite $\mathrm{MgH}_{2} / 5 \mathrm{MG}$ $\mathrm{Zr}_{2} \mathrm{Pd}$ button measured at different temperatures $(50,100,150,175$, and $200{ }^{\circ} \mathrm{C}$ ) under 10 bar of $\mathrm{H}_{2}$. The hydrogenation kinetics measured at $200{ }^{\circ} \mathrm{C} / 10$ bar $\mathrm{H}_{2}$ for pure $\mathrm{MgH}_{2}$ obtained after $50 \mathrm{~h}$ of RBM and then consolidated at $350^{\circ} \mathrm{C}$ is shown in (b).

min), as displayed in Fig. 10a. This sample tends to attain its maximum storage capacity of $6.08 \mathrm{wt} \% \mathrm{H}_{2}$ after only $10 \mathrm{~min}$ (Fig. 10a). When $\mathrm{MgH}_{2}$ powders were doped with a high $\mathrm{Zr}_{2} \mathrm{Pd}$ concentration (10 wt\%), no further improvement in kinetics could be seen, as indicated by the low storage capacities of 2.88 and $3.05 \mathrm{wt} \% \mathrm{H}_{2}$ obtained after 5 and $10 \mathrm{~min}$, respectively, as displayed in Fig. 10a. After 10 min of hydrogenation time, the sample reached its saturation value of $3.25 \mathrm{wt} \% \mathrm{H}_{2}$ (Fig. 10a).

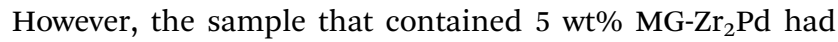
a higher mass $\%$ of the catalytic agent compared with one that contained only $2.5 \mathrm{wt} \% \mathrm{MG}-\mathrm{Zr}_{2} \mathrm{Pd}$, showed a higher hydrogen storage capacity of $6.1 \mathrm{wt} \%$. Based on morphological examinations, we found that $5 \mathrm{wt} \% \mathrm{MG}-\mathrm{Zr}_{2} \mathrm{Pd}$ contained numerous micropores, which acted as hydrogen diffusion gateways to facilitate a better and fast hydrogen diffusion. In contrast to this and based on SEM investigations, we found that a large volume fraction of $\mathrm{MG}^{-} \mathrm{Zr}_{2} \mathrm{Pd}$ nanopowders was agglomerated together due to electrostatic attractions and van der Waals phenomenon. These aggregated glassy nanoparticles failed to penetrate the $\mathrm{MgH}_{2}$ matrix and were abundantly distributed far from the 
metal hydride powders. Thus, $\mathrm{MgH}_{2} / 5 \mathrm{wt} \% \mathrm{MG}-\mathrm{Zr}_{2} \mathrm{Pd}$ presented the best composition in this study.

After studying the effect of $\mathrm{MG}-\mathrm{Zr}_{2} \mathrm{Pd}$ on the kinetics of $\mathrm{MgH}_{2}$ powders, we investigated the effects of consolidation and temperature on the hydrogenation kinetics of the nanocomposite $\mathrm{MgH}_{2} / 5$ wt $\%$ MG- $\mathrm{Zr}_{2} \mathrm{Pd}$ button (Fig. 10b). The hydrogenation kinetics of the consolidated sample, which was measured at $200{ }^{\circ} \mathrm{C}$, showed superior kinetics, indicated by the very short time required to absorb 5.74 and $6.08 \mathrm{wt} \% \mathrm{H}_{2}$ within 2.5 and $7.5 \mathrm{~min}$, respectively, as indicated in Fig. 10b. By comparing these values with those for the powder sample, we can conclude that the hot pressing led to improved gas uptake kinetics. This significant improvement of the hydrogenation kinetics can be attributed to two reasons: (i) the introduction of high intensity lattice imperfections and plastic deformation to the sample upon repressing for 50 cycles (Fig. $8 \mathrm{~b}$ and c), and (ii) the formation of a micropore network in the sample, which was developed due to the penetration of the $\mathrm{Mg}$ matrix by hard, spherical, $\mathrm{Zr}_{2} \mathrm{Pd}$ nanoparticles (Fig. 1). It can be claimed that the present fabricated system has superior absorption kinetics compared with pure $\mathrm{MgH}_{2}$ button measured at the same temperature $\left(200^{\circ} \mathrm{C}\right)$ that required a very long time $(31.5 \mathrm{~min})$ to absorb only $2.74 \mathrm{wt} \% \mathrm{H}_{2}$ (Fig. 10b).

The gas uptake kinetics of the consolidated sample slightly decreased with the decrease in the absorption temperature to $175{ }^{\circ} \mathrm{C}$ and $150{ }^{\circ} \mathrm{C}$, respectively (Fig. 10b). This can be realized from the rather long time that was needed to absorb $5.49 \mathrm{wt} \%$ $\mathrm{H}_{2}\left(7.5 \mathrm{~min} / 175^{\circ} \mathrm{C}\right)$ and $5.43 \mathrm{wt} \% \mathrm{H}_{2}\left(150{ }^{\circ} \mathrm{C}\right)$, as displayed in Fig. 10b. Further decreasing the absorption temperature to $100{ }^{\circ} \mathrm{C}$ and $50{ }^{\circ} \mathrm{C}$ led to a dramatic decrease in the storage capacity of $\mathrm{Mg}$, which tended to uptake $2.45 \mathrm{wt} \% \mathrm{H}_{2}$ and $1.1 \mathrm{wt} \% \mathrm{H}_{2}$, respectively (Fig. 10b).

The corresponding dehydrogenation kinetics of the nanocomposite $\mathrm{MgH}_{2} / 5$ wt $\%$ MG- $\mathrm{Zr}_{2} \mathrm{Pd}$ button was measured at different temperatures under 0.4 bar of $\mathrm{H}_{2}$, and the results are plotted in Fig. 11. The as-consolidated pure $\mathrm{MgH}_{2}$ button

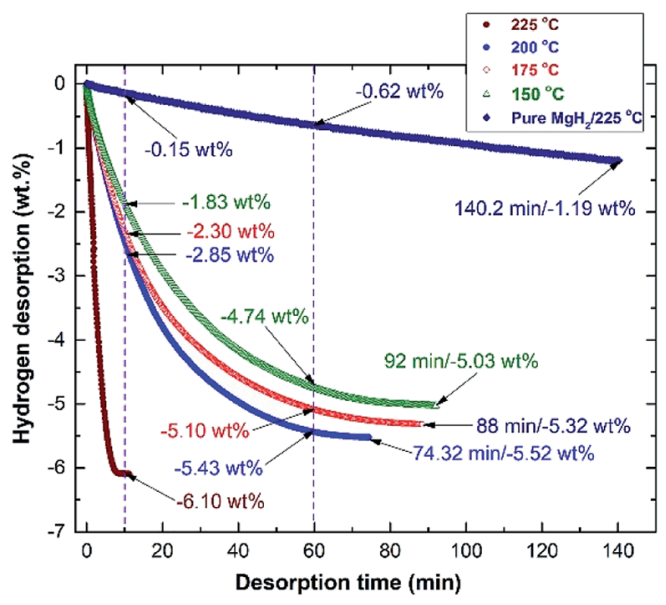

Fig. 11 Dehydrogenation kinetics of the hot-pressed nanocomposite $\mathrm{MgH}_{2} / 5 \mathrm{MG}-\mathrm{Zr}_{2} \mathrm{Pd}$ button measured at different temperatures (150, $175,200,175$, and $225^{\circ} \mathrm{C}$ ) under 0.4 bar of $\mathrm{H}_{2}$. Gas releasing kinetics measured at $225^{\circ} \mathrm{C}$ for pure $\mathrm{MgH}_{2}$ obtained after $50 \mathrm{~h}$ of $\mathrm{RBM}$, and then consolidated at $350^{\circ} \mathrm{C}$ is shown in the figure for comparison.
(0 wt $\% \mathrm{Zr}_{2} \mathrm{Pd}$ ) revealed very slow dehydrogenation kinetics at $225{ }^{\circ} \mathrm{C}$, as indicated by the very long time (140.2 min) required to release only $-1.19 \mathrm{wt} \%$, as displayed in Fig. 11. In contrast, when $\mathrm{MgH}_{2}$ was milled with $5 \mathrm{wt} \% \mathrm{Zr}_{2} \mathrm{Pd}$ before consolidation at $350{ }^{\circ} \mathrm{C}$, a significant improvement in gas releasing kinetics was attained at $225^{\circ} \mathrm{C}$ (Fig. 11). This is characterized by the very short time consumed (10 $\mathrm{min}$ ) to discharge the full capacity of the sample $\left(-6.10 \mathrm{wt} \% \mathrm{H}_{2}\right)$, as presented in Fig. 11.

Decreasing the desorption temperature to $200{ }^{\circ} \mathrm{C}, 175^{\circ} \mathrm{C}$ and $150^{\circ} \mathrm{C}$ led to a serious decrease in the hydrogen release from the samples to $-2.85,-2.3$ and $-1.83 \mathrm{wt} \%$, respectively (Fig. 11). An obvious improvement in dehydrogenation kinetics was obtained when the time was increased to $60 \mathrm{~min}$. This is implied by the dramatic increase of the gas discharge to be $-5.43,-5.1$ and $-4.74 \mathrm{wt} \% \mathrm{H}_{2}$, measured at $200{ }^{\circ} \mathrm{C}, 175{ }^{\circ} \mathrm{C}$ and $150{ }^{\circ} \mathrm{C}$, respectively (Fig. 11). These samples were able to fully discharge their hydrogen capacities of $-5.52,-5.53$ and $-5.03 \mathrm{wt} \%$ within 74.32, 88, and $92 \mathrm{~min}$, respectively, as elucidated in Fig. 11.

\section{Cycle-life-time}

Hydrogenation/dehydrogenation cyclability is a very important characterization technique used here to examine the capability of the nanocomposite $\mathrm{MgH}_{2} / 5 \mathrm{wt} \% \mathrm{MG}-\mathrm{Zr}_{2} \mathrm{Pd}$ button to achieve continuous hydrogen charging/discharging for a long time without failure or serious degradation. The cycle-life-time curve of the consolidated sample obtained at $225{ }^{\circ} \mathrm{C}$ under the uptake/release pressures of 10/0.5 bar of $\mathrm{H}_{2}$ is presented in Fig. 12a. The bulk sample was first treated under high
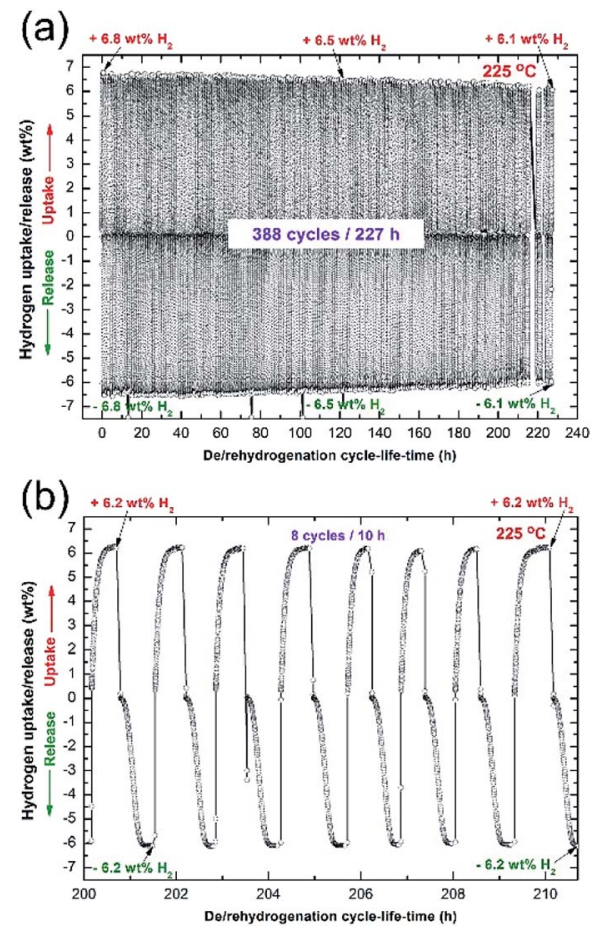

Fig. 12 (a) Cycle-life-time curve of hot-pressed nanocomposite $\mathrm{MgH}_{2} / 5 \mathrm{MG}-\mathrm{Zr}_{2} \mathrm{Pd}$ button measure at $225{ }^{\circ} \mathrm{C}$ at hydrogenation and dehydrogenation hydrogen pressure of 10 bar and 0.4 bar, respectively. The last 8 cycles in (a) are individually displayed in (b). 
temperature/pressure $\left(350{ }^{\circ} \mathrm{C} / 35\right.$ bar $\left.\mathrm{H}_{2}\right)$ for $24 \mathrm{~h}$ to ensure the removal of the $\mathrm{MgO}$ layer coated on the button. This activation step was necessary to improve the kinetics and to increase the hydrogen storage capacity to approach a high value of $6.8 \mathrm{wt} \%$ (Fig. 12a).

In general, the sample showed a good performance by achieving 388 cycles within $227 \mathrm{~h}$ without kinetic degradation, as presented in Fig. 12a. However, the sample suffered from a monotonical decrease on its storage capacity, as suggested by the hydrogen capacity decrease attained after 120 h (Fig. 12a). Hydrogen capacity was continuously decreased with the increasing cycle-life-time, which approached $6.1 \mathrm{wt} \%$, as displayed in Fig. 12a. The last 8 cycles, presented in Fig. 12b, indicate that hydrogenation/dehydrogenation kinetics maintained their capability of achieving fast gas uptake/release processes.

Fig. 13a presents the FE-HRTEM image of the nanocomposite $\mathrm{MgH}_{2} / 5 \mathrm{wt} \% \mathrm{MG}-\mathrm{Zr}_{2} \mathrm{Pd}$ sample after achieving 388 cycles (Fig. 12a). The sample was composed of $\mathrm{Mg}$ powder particles ( $\sim 12 \mathrm{~nm}$ in diameter) surrounded by spherical MG$\mathrm{Zr}_{2} \mathrm{Pd}$ nanoparticles, as shown Fig. 13a. The SADP (Fig. 13a) taken from the circular zone indexed in Fig. 12a revealed a spotlike diffraction related to hcp-Mg [001] overlapped with the halo-diffuse pattern of the $\mathrm{MG}^{-} \mathrm{Zr}_{2} \mathrm{Pd}$ phase, as elucidated in Fig. 13b. An atomic resolution TEM image of the red-zone indexed in Fig. 13a is displayed in Fig. 13c. The sample possessed the nanocrystalline structure of $\mathrm{Mg}$ metal, characterized by a number of lattice fringes as presented in Fig. 13c.



Fig. 13 FE-HRTEM image of a sample obtained after completion 388 cycles is shown in (a) together with its corresponding SADP (b) taken from the area indexed in (a). The atomic resolution TEM image of a near-edge zone presented in(s) is displayed in (c).
However, a small volume fraction of undecomposed $\mathrm{MgH}_{2}$ particles existed, as indicated by the presence of $\beta-\mathrm{MgH}_{2}(200)$. It is noteworthy to mention that hard $\mathrm{MG}^{-} \mathrm{Zr}_{2} \mathrm{Pd}$ nanoparticles surrounded $\mathrm{Mg}$ particles played an important role in preventing the metal from severe grain growth. Thus, they can be considered as grain growth inhibitors, facilitating good performance of the $\mathrm{Mg}$ metal while enhancing its hydrogen storage behavior.

\section{Conclusions}

A solid-state hydrogen storage binary system of $\mathrm{MgH}_{2} / 5 \mathrm{wt} \%$ MG- $\mathrm{Zr}_{2} \mathrm{Pd}$ nanocomposite powder was fabricated by a highenergy ball milling technique. A 20-ton hot-press operated at $350{ }^{\circ} \mathrm{C}$ was employed to consolidate the nanocomposite powders obtained after $50 \mathrm{~h}$ of milling. The as-consolidated buttons were severely plastically deformed upon cycling loading for 50 cycles at $150{ }^{\circ} \mathrm{C}$. The cycled-buttons maintained their original nanograin characteristics without undergoing an undesired grain growth. The loading/unloading strategy used in the present study had significant beneficial effects on improving the hydrogen storage behavior of the nanocomposite system. This is indicated by the fast gas uptake and release of $6.08 \mathrm{wt} \% \mathrm{H}_{2}$ within $7.5 \mathrm{~min}$ and $10 \mathrm{~min}$ at $200{ }^{\circ} \mathrm{C}$ and $225{ }^{\circ} \mathrm{C}$, respectively. The $E_{\mathrm{a}}$ of the decomposition, which was calculated to be $92.2 \mathrm{~kJ} \mathrm{~mol}^{-1}$, is far below than the one calculated for pure nanocrystalline $\mathrm{MgH}_{2}$ powders $\left(151.2 \mathrm{~kJ} \mathrm{~mol}^{-1}\right)$.

The morphological examinations conducted for this system indicated that the hard $\mathrm{MG}-\mathrm{Zr}_{2} \mathrm{Pd}$ spherical nanopowders were forced to penetrate into the $\mathrm{Mg} / \mathrm{MgH}_{2}$ matrix to create micro/ nanopore structures upon pressing for 50 cycles. These ultrafine glassy powders occupied their catalytic sites in those pores (hydrogen diffusion pathways) to facilitate fast hydrogen absorption and desorption processes and to prevent the undesired growth of $\mathrm{Mg} / \mathrm{MgH}_{2}$ grains. The newly fabricated nanocomposite system had excellent cyclability, indicated by the achievement of continuous cycles (338 cycles) at $225^{\circ} \mathrm{C}$ without degradation over $227 \mathrm{~h}$.

\section{Conflicts of interest}

There are no conflicts to declare.

\section{Acknowledgements}

This work has been partially funded by Kuwait Foundation for the Advancement of Sciences (KFAS) related to the Project EA078C under a contract number: PR1814SP12. The financial support received by the Kuwait Government through the Kuwait Institute for Scientific Research for purchasing the equipment used in the present work, using the budget dedicated for the project led by the first author (P-KISR-06-04) of Establishing Nanotechnology Center in KISR is highly appreciated.

\section{Notes and references}

1 R. Bardhan, A. M. Ruminski, A. Brand and J. J. Urban, Energy Environ. Sci., 2011, 4, 4882-4895. 
2 A. Schneemann, J. L. White, S. Y. Kang, S. Jeong, L. F. Wan, E. S. Cho, et al., Chem. Rev., 2018, 118, 10775-10839.

3 T. Latake, P. Pawar and C. Ranveer, International Journal of Innovative Research and Creative Technology, 2015, 1, 333337.

4 M. S. El-Eskandarany, RSC Adv., 2019, 9, 9907-9930.

5 B. Jackson, L. Quéré, M. Andrew, G. Canadell, P. Peters, J. Roy, et al., Environ. Res. Lett., 2017, 12, 110202.

6 B. Song, Y. Zhou, H.-M. Yang, J.-H. Liao, L.-M. Yang, X.-B. Yang and E. Ganz, J. Am. Chem. Soc., 2019, 141, 36303640 .

7 L.-M. Yang, V. Bačić, I. A. Popov, A. I. Boldyrev, T. Heine, T. Frauenheim and E. Ganz, J. Am. Chem. Soc., 2015, 137, 2757-2762.

8 J.-H. Liu, L.-M. Yang and E. Ganz, ACS Sustainable Chem. Eng., 2018, 6, 15494-15502.

9 J.-H. Liu, L.-M. Yang and E. Ganz, J. Mater. Chem. A, 2019, 7, 3805-3814.

10 J.-H. Liu, L.-M. Yang and E. Ganz, J. Mater. Chem. A, 2019, 7, 11944-11952.

11 L. Xu, L.-M. Yang and E. Ganz, Theor. Chem. Acc., 2018, 137, 98, DOI: 10.1007/s00214-018-2270-8.

12 K. Fu, J. Chen, R. Xiao, J. Zheng, W. Tian and X. Li, Energy Environ. Sci., 2018, 11, 1563-1570.

13 P. Jain, Int. J. Hydrogen Energy, 2009, 34, 7368-7378.

14 A. Yarts, V. Lototskyy, E. Akiba, A. Albret, E. Antonov, R. Ares, et al., Int. J. Hydrogen Energy, 2019, 44, 7809-7859.

15 M. S. El-Eskandarany, Mechanical Alloying: Nanotechnology, Materials Science and Powder Metallurgy, Elsevier Inc., Oxford, 2nd edn, ch. 9, 2015.

16 A. Sartbaeva, V. L. Kuznetsov, S. A. Wells and P. P. Edwards, Energy Environ. Sci., 2008, 1, 79-85.

17 C. Weidenthaler and M. Felderhoff, Energy Environ. Sci., 2011, 4, 2495-2502.

18 P. Jain, C. Lal and A. Jain, Int. J. Hydrogen Energy, 2010, 35, 5133-5144.
19 C. Zhou, Z. Fang and C. Bowman, J. Phys. Chem. C, 2015, 119, 22261-22271.

20 J. Chen, G. Xia, Z. Guo, Z. Huang, H. Liu and X. Yu, J. Mater. Chem. A, 2015, 3, 15843-15848.

21 X. Ding, Y. Li, F. Fang, D. Sun and Q. Zhang, J. Mater. Chem. A, 2017, 5, 5067-5076.

22 T. Liu, X. Ma, C. Chen, L. Xu and X. Li, J. Mater. Chem. C, 2015, 119, 14029-14037.

23 B. Yu, X. Yang, K. Liu, M. Grant and S. Walker, Int. J. Hydrogen Energy, 2010, 35, 6338-6344.

24 S. Agarwal, A. Aurora, A. Jain, I. P. Jain and A. Montone, Int. J. Hydrogen Energy, 2009, 34, 9157-9162.

25 C. Zhou, Z. Fang, C. Ren, J. Li and J. Lu, J. Mater. Chem. C, 2013, 117, 12973-12980.

26 Y. Fu, M. Groll, R. Mertz and R. Kulenovic, J. Alloys Compd., 2008, 460, 607-613.

27 M. S. El-Eskandarany, E. Shaban, H. Al-Matrouk, M. Behbehani, A. Alkandary, F. Aldakheel, et al., Materials Today Energy, 2017, 3, 60-71.

28 M. S. El-Eskandarany, Sci. Rep., 2016, 6, 26936.

29 M. S. El-Eskandarany, H. Al-Matrouk, M. Behbehani, E. Shaban, A. Alkandary, F. Aldakheel, et al., Mater. Chem. Phys., 2018, 203, 17-26.

30 M. S. El-Eskandarany, RSC Adv., 2019, 9, 1036.

31 M. S. El-Eskandarany, M. Saeed, E. Al-Nasrallah, M. Banyan and F. Al-Ajmi, Energies, 2019, 12, 1005.

32 K. Pandey, A. Bhatnagar, S. Mishra, P. Yadav, A. Shaz and N. Srivastava, J. Phys. Chem. C, 2017, 121, 24936-24944.

33 N. S. Mustafa, N. N. Sulaiman and M. Ismail, RSC Adv., 2016, 6, 110004-110010.

34 N. A. Ali, N. H. Idris, M. F. Md Din, N. S. Mustafa, N. A. Sazelee, F. A. Halim Yap, et al., RSC Adv., 2018, 8, 15667-15674.

35 Y. Liu, J. Zou, X. Zeng and W. Ding, RSC Adv., 2015, 5, 76877696. 